\title{
The potential of OBOR energy cooperation and its solution
}

\author{
Zehu $\operatorname{Jin}^{1 ' a}$ and ${ }^{2, b}$ \\ ${ }^{1}$ School of economics, Anhui university, Hefei, China \\ ${ }^{2}$ School of energy and environment, Southeast University, Nanjing, China \\ *Corresponding author e-mail: 12015@ahu.edu.cn, *23023954394@qq.com
}

Keywords: OBOR, Energy cooperation, Focus on areas, China standard

\begin{abstract}
The "One Belt and One Road"(OBOR) region occupies a central position in the global energy supply and is the main source of China's energy imports. OBORenergy cooperation has great potential. There are many areas of cooperation that can be focused on. But the potential for cooperation are not fully released, the security of supply security system also has not yet been established, the benefits of trade and investment has yet to be promoted, and the ability to communicate with local communities needs to be strengthened.Therefore, we must seekto break through from multiple levels such as the system arrangement, finance, network and infrastructure, docking mechanism etc, and then to break the bottleneck ofOBOR regional energy cooperation.
\end{abstract}

\section{Potential analysis of "OBOR" energy cooperation}

On May 12, 2017, China National Energy Administration issued "promote The Silk Road Economic Belt and the 21st Century Maritime Silk Road vision and action of energy cooperation", put forward the energy cooperation to adhere to the six principles of tolerance, mutual benefits, open market operation, safe development, green development and harmonious development, which also indicatedthe determination that China leads the way for friendly cooperation and jointly promote the development of global energy with "OROB" regional countries.

The energy resources all the way along "OBOR" area is abundant, theprovenrecoverable reserves remain 132.54 billion tons for oil, 157.99935 trillion $\mathrm{m} 3$ for gas, 446.2 billion tons for coal, and of 130 tonsforreliable uranium resource ( $\$ 130$ / $\mathrm{kg}$ or less), which accounts for $58.7 \%, 79.4 \%, 50.1 \%$ and $23.3 \%$ of the world's total reserves, respectively, (table 1). Clean energy resources is extremely rich at the same time. According to the estimationofworld energy council,the theoretical production of global clean energy is equal to 45 trillion tons of standard coal approximately, while the theoreticalconsumptionof global primary energy amount is about 20 billion tons of standard coal, proven that clean energy is enough to support the global energy consumption. In Asia, the main region of "OBOR", and Africa with the potential for future cooperation , the total amount of clean energy is more than half of the total world (table 2).

\begin{tabular}{|c|c|c|c|c|c|c|}
\hline \multicolumn{7}{|c|}{ table 1 Major fossil energy distribution of "0BOR" region } \\
\hline \multirow[b]{2}{*}{ Areas } & \multicolumn{2}{|l|}{$0 \mathrm{il}$} & \multicolumn{2}{|l|}{ Gas } & \multicolumn{2}{|l|}{ Coal } \\
\hline & $\begin{array}{l}\text { The remaining proved recoverable } \\
\text { reserves (hundred million tons) }\end{array}$ & Percentage & $\begin{array}{l}\text { The remaining proved recoverable } \\
\text { reserves (hundred million tons) }\end{array}$ & \begin{tabular}{|c|} 
Percentage \\
$\%$
\end{tabular} & $\begin{array}{l}\text { The remaining proved recoverable } \\
\text { reserves (hundred million tons) }\end{array}$ & 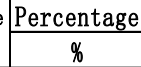 \\
\hline Middle East & 1094 & 47.9 & 80 & 43.2 & 11 & 0.1 \\
\hline Africa & 173 & 7.7 & 14 & 7.6 & 318 & 3.6 \\
\hline Asia and Pacific & 56 & 2.5 & 15 & 8.2 & 2884 & 32.4 \\
\hline Europe & 98 & 8.8 & 57 & 30.6 & 3105 & 34.8 \\
\hline \multicolumn{7}{|c|}{ table 2 Major renewable energy distribution of "0BOR" region } \\
\hline \multirow{3}{*}{ Areas } & \multicolumn{2}{|l|}{ Wind energy } & \multicolumn{2}{|l|}{ Hydroenergy } & \multicolumn{2}{|l|}{ Solar energy } \\
\hline & \multirow{2}{*}{$\begin{array}{c}\text { Theoretical reserves (thousand } \\
\text { billion } \mathrm{kW} / \mathrm{h} \text { per year) }\end{array}$} & Percentage & \multirow{2}{*}{$\begin{array}{c}\text { Theoretical reserves (thousand } \\
\text { billion } \mathrm{kW} / \mathrm{h} \text { per year) }\end{array}$} & Percentage & \multirow{2}{*}{$\begin{array}{c}\text { Theoretical reserves (thousand } \\
\text { billion } \mathrm{kW} / \mathrm{h} \text { per year) }\end{array}$} & Percentage \\
\hline & & $\%$ & & $\%$ & & $\%$ \\
\hline Africa & 173 & 7.7 & 14 & 7.6 & 318 & 3.6 \\
\hline Asia & 56 & 2.5 & 15 & 8.2 & 2884 & 32.4 \\
\hline Europe & 98 & 8.8 & 57 & 30.6 & 3105 & 34.8 \\
\hline
\end{tabular}


However, the abundant energy resources along the region is not fully developed, which accounts for about $40 \%$ of world energy production, with compare toaround $30 \%$ of energy consumption, energy production and consumption of annual growth rate remained at about 3\%as shown in figure 1. Most of the"OBOR" regional countries are energy - based growth models; In addition, energy consumption is much lower than energy production, indicating that it is mainly responsible for the role of suppliers in the world energy system. Despite the slow growth of global energy consumption, the per capita energy consumption level is far away from the global average level. China has good development experience in the transformation and upgrading of energy industry and the use of technology. It can help "OBOR" regionaldeveloping countries that need to break through the bottleneck of economic development.

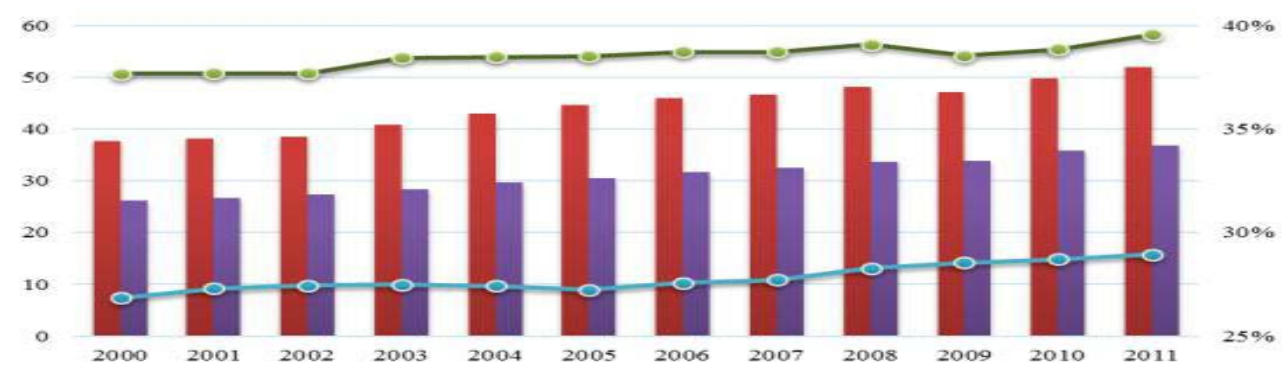

Note: Red column- Energy output (100 million tons of oil equivalent). Blue column- Energy consumption (100 million tons of oil equivalent).

The curve above-Production accounts for the world's share. The curve below-Consumption accounts for the world's share.

Figure 1 2000-2011"OBOR"countries energy production and consumption

\section{2 five major areas of "OBOR" energy cooperation}

\subsection{Resources exploitation and transportation.}

According to the IEA's forecast, in the next 15 years, traditional fossil energy as the main energy will still be the main body of the world's energy consumption in aggregate, oil, gas and coal will still account for most of the energy consumption. In Mongolia, Indonesia, Pakistan, and other countries with abundant fossil resource, limited by mining and transportation technology, the utilization degree of oil, gas and coal resources is low, if technical support can be provided for these countries, such resources will not only meet the local energy need but also can be exported to other countries at the same time. Relying on crude oil pipeline onshore, which has been built between China and central Asia - Russia, China and Myanmar natural gas pipeline, coal international railway channel,the pipeline network of regional resources has been built to increase the liquidity and the overall safety of oil and gas, coal resources; when it comes to maritime aspects, new multimodal combined transport by rail and sea routes is blazed, there are other methods including improvingtheshipping and port capacity, establishing of early warning mechanism to meet all kinds of possible riskin view of the sea transport, and safeguarding the safety of maritime energy routes together with the neighboring countries.

\subsection{Infrastructure construction.}

In addition to the facilities needed to ensure energy supply, it is significant to build the grid. The densely populated Asia-pacific region results in a huge electricity demand, however, the imbalance of resources has caused the conflict of power allocation between region abundant with electricity and region short of eletricity. For the countries and regions whose grid infrastructure backwardness is unable to meet their public power need, we can help them realize of power grid upgrading,export the power standards in China, and integrates cross-border power deals and power grids at the same time. China can connect the grid to the surrounding countries and the region first, and continue to improve the power network facilities with South Asia, southeast Asia, with Russia's dc network 
engineering, in addition, xinjiang and the five central Asian countries of uhv power transmission network, northeast power grid construction is also the focus of the interconnection in the future

\subsection{Energy utilization and transformation.}

To improve energy production, transformation and utilization efficiency, the green and efficient clean low-carbon transformation of energy economy is the core element of "OBOR" green energy cooperation. With the export credit facility coal unit major coal country export standards published in OECD "official support export credit arrangementcompare to the current value of atmospheric pollutant emission standards, China's coal technology and environmental protection standards are one of the world's leading level, rather than backward production capacity. In countries with low economy and low electrification degree, it is more suitable to promote efficient and clean coal power and energy-saving technologies. Hydro, wind, solar and other renewable energy are in a more balanced global distribution, promoting regional renewable energy development can effectively help countries with a deficiency of fossil energy in electricity poverty. According to the resource endowment and future energy planning of various regions, the renewable energy types and installed capacity in 2015 are summarized(table 3).

\begin{tabular}{|c|c|c|}
\hline \multicolumn{3}{|c|}{ table 3 renewable energy types and 2015 planned installed capacity } \\
\hline countries and regions & renewable energy types & 2015 planned installed capacity \\
\hline South Asia, Southeast Asia & Photovoltaic (pv), wind power, hydroeletricity, biomass & 148513 \\
\hline Central Asia & hydroeletricity, Photovoltaic (pv), wind power & 12401 \\
\hline Central and Eastern Europe & Photovoltaic (pv), wind power, hydroeletricity & 54096 \\
\hline West Asia, the Middle East & Photovoltaic (pv), hydroeletricity, wind power, nuclear & 65212 \\
\hline
\end{tabular}

\subsection{Energy services and equipment.}

Energy services including think-tankservice, product certification, project design and evaluation, upgraded, training and financial investment, etc, can effectively improve the energy efficiency of development, transformation and utilization. Relying on our energy service industry professional technology and service products can provide the countries along the waywith the energy-intensive enterprises reform, exploration and exploitation of resources, power grid construction fund, product and intellectual support. In terms of equipment manufacturing, the technical parameters of ultra-supercritical coal-fired units in China is higher than foreign standards, wind power tower, turbine, renewable energy equipment such as solar panels, and the third generation of nuclear power equipment has a strong international competitiveness in terms of performance and cost. The "go out"strategy of these services and equipment will greatly help the energy development of countries along the belt and road, providing great support for the "OBOR" initiative.

2.5 Energy governance platform. The new international energy governance platform should include three parts: "OBOR" international energy cooperation platform, new international energy finance system and multi-party dialogue and coordination mechanism. We should expand and deepen cooperation with existing international energy administration, establish new international relations, and energy superpower energy innovation cooperation mode, seek to win more energy cooperation opportunities, promote "area along the" green energy development strategy.

\section{Problems and risks of "OBOR" energy cooperation}

First, the potential for "OBOR" energy cooperation has not yet been fully released. In terms of trade volume, most of China's energy imports come from the "OBOR" region, which is roughly the same as the "OBOR" regional energy export in the global supply system. But if we look at the impact of trade, our influence is relatively weak. China is the "OBOR"region's largest energy importer, but neither trade center nor pricing center of oil and gas locates in "OBOR" regions or China, the price is determined by third countries. What is more, in the process of pricing, financial function plays a more and more important role, which magnified the impact of energy price fluctuations, and has a great negative impacton consumer pricesinoil producer and the international 
balance between income andpayments. In the field of investment, while China has certain investmentin the area of the country's oil and gas and electricity, but this kind of investment hasa larger gap with compare to China's imports and China's current engineering construction ability, there is still huge room to improvefuture investment.

Second, the security system for energy security is not yet established. Although China's main energy transport channels are concentrated in the "OBOR" region, the safe and unimpeded transport system has not yet been established. Taking oil transportation for instance, $80 \%$ of China's crude oil is transported by sea, and $80 \%$ of the amount of shipping passes through the strait of malacca, and $38 \%$ passes through the strait of hormuz, but theChinainfluence and security capabilities in the areaare very limited. In addition, from the carrier's point of view, less than 20 per cent of offshore oil imports are carried by Chinese vessels.

Third, the economic benefits of investment in energy trade remain to be improved. Many energy cooperation projects are currently losing money. In 2008, for example, China signed a high price contract for liquefied natural gas (LNG) with Qatar, which is still in a serious deficit. There are three reasons for the loss of the project. First, in the context of high oil prices and energy supply and demand, oil importers, including China, generally have higher prices. Then, China's enterprises onlyparticipate in trade linkbutare absent from the investment, so the high price of imports cannot compensate by upstream investment income, whileJapan,South Korean companies tend to take a stake inthe gas production countries participation project, upstream of the downstream of investment benefit can to a certain extent hedge trade risk. Finally, it is concerned to ensure national energy security and the overall situation of national diplomacy. From the point of view of energy security, finding a stable gas source is an important factor, from promoting foreign speaking, a big project develops the bilateral relations of cooperation, as a result of the project contract in unreasonable high price. At this price, many Japanese and Korean importers have dropped their contracts, but China's state-owned enterprises have signed high-priced contracts from the perspective of ensuring energy security and promoting bilateral relations. The above project is a typical case, and there are many such investment projects existed.

Fourth, some projects have insufficient communication with local area during the construction and operation. Taking China power investment group's dense pine hydropower station as an example, considering the economy and driving the local economic and social development, solving the shortage of electricity in the local comprehensive benefits, such a large engineering project is very good. Although the project is in the government's power within the framework of the cooperation agreement between the two countries, and fulfilled all the formalities, but due to lack of local complicated political situation and unique cultural habits, especially the lack of communication and coordination with nongovernmental organizations, the project is postponed for a long time. This not only led to a huge interest loss in early investment, but also had a negative impact on cooperation between us.

\section{Countermeasures and Suggestions}

\subsection{Build a system of energy supply and demand in the "OBOR" region and improve the multilateral mechanism for energy cooperation.}

We should construct multi-level, from multiple sources, multi-channel, omni-directional overseas energy resources development and utilization of strategic synergy reasonably, adhere to the green, sustainableprinciple, booster along the"OBOR" region's economic development and energy transformation, exhibit Chinse green leadership in the international platform, perfecting global energy governance in China, Europe and east Asia energy importers as well as the common wishes of the energy supplier, "OBOR" region countries should strengthen mutual communication to eliminate barriers, enhance mutual trust, set up efficient coordination mechanism, undergo the whole industry chain cooperation in energy exploitation, processing, transportation, trade and 
consumption. We will work to build a regional energy market, build a multilateral energy cooperation platform, and establish an energy security concept in Asia.

\subsection{Build an Asian energy financial system in the "OBOR" region}

We will increase the size of local currency settlement in energy trade, promote the use of RMB settlement, and strive for a say in energy pricing. At present, the level of energy finance in central Asia, Russia and asia-pacific countries in the "OBOR" region is low, and it is possible to promote the establishment of the Asian energy finance system with China as the leading power. "OBOR", especially the silk road economic belt, is a vast and resource-rich country along the routes, which is known as the "strategic energy and resource base of the 21st century". Most of these countries are lagging behind in their economic development. They are looking for energy resources to take the road to the rich world and actively seek energy cooperation with our country. We should increase energy investment in the region and ensure the diversification and energy security of our energy sources while contributing to the poverty reduction in the host country.

\subsection{Strengthen the "OBOR" energy network and infrastructure construction}

Energy cooperation is an important pillar of drive all the way along "OBOR", and successful energy cooperation, especially in the network, transport, power grid contains infrastructure facilities such as energy cooperation projects, if successful implemented, they will work as a bridge between our country and neighboring countries. At present, we should build the infrastructure network fulcrum of "OBOR" peripheral energy channel and lay the foundation for the free circulation of energy in the region. Especially in oil and gas pipelines, power supply base and power grid interconnection, it provides basic guarantee for international energy cooperation. We should optimize and promote oil and gas cooperation with Russia, central Asia, the Middle East, Africa, the Americas, Asia Pacific and other regions, relying on technology, cost advantages, hydropower, nuclear power, wind power, solar energy and other clean renewable energy cooperationcan be actively promoted, in the country short of electricity, we must give full consideration to local needs and external constraints and develop clean and efficient, regional water-saving coal.

\subsection{Enterprises' "huddle" shall enhance the competitiveness of international energy, and choose the cooperation strategy, mode of investment and scale, and spread the risk of cooperation.}

We should avoid disorder and vicious competition and make full use of the overflow effect of the resources of the first mover; In accordance with local relevant policies and laws, project investment should be integrated into local community life and undertake social and environmental responsibilities. We will improve the "OBOR" green financial mechanism, adhere to the principle of "enterprise as the main body, market operation, mutual benefit ", and maintain the sustainability of funds. We are supposed to guide the government, financial, business and other public organizations to participate in public management, avoid conflict community and mandatory management, in accordance with both sides talks things over, follow society after the market first, then the government's governance order, realize the diversification of energy cooperation, marketization and ordering.

\subsection{Connect with international energy standards and mechanisms and promote the "Chinese standard" through green energy cooperation.}

"OBOR" green development is in line with the theme of global energy green transformation, and the development of green, low-carbon, new, renewable resources have become a global consensus. The new energy is the inevitable trend of the future international energy industry development. We should take active actions to build the "OBOR" green energy development architecture. China has certain industrial advantages in the new energy sector, which can export technology, equipment and capital as traditional industries. In photovoltaic industry, for example, to strengthen the Chinese and 
foreign cooperation will not only promote the national and regional ecological protection, industrial development, and the effect to reduce emissions, but also bring opportunities to the development of China's major photovoltaic enterprise.. In nuclear power, clean and efficient coal, renewable energy and uhv transmission and so on, China is in the world leading level, and equipment costs are also reduced year by year, "the Chinese standard" can greatly reduce the resistance of Chinese enterprises "going out", facilitating regional energy connectivity.

\section{References}

[1] Yuan Jiahai. What is the prospect of "One Belt And One Road" green energy cooperation http://www.in-en.com/article/html/energy-2262234.shtml

[2] Yang Chenxi. "One Belt And One Road" regional energy cooperation in energy cooperation and the new vision of coping strategies: New field of vision $\quad 2014,4,124-128$

[3] Wang Jinzhao. The thinking and policy of "One Belt And One Road" energy cooperation: national governance weekly 2016-07-25 